\title{
The hidden hand of neoliberal global institutions: The World Bank and the Reshaping of Botswana Public Sector
}

\author{
Dr. M.N. S. Marobela (Corresponding author) \\ The University of Botswana, Department of Management \\ P.O.Box 490 AEH, Gaborone .Botswana \\ Email: mmarobela@mopipi.ub.bw, Tel: + 267 3555023, Fax: + 2673554580 \\ Mr. Rudolph. L. Boy \\ The University of Botswana, Department of Management \\ P.O.Box 490 AEH, Gaborone .Botswana \\ Email: rudolph.boy@mopipi.ub.bw
}

Received: May 18, 2012 Accepted: June 25, 2012 DOI: 10.5296/jpag.v2i2.2040

\begin{abstract}
This paper examines how powerful international institutions work to influence the reforms trajectory in the developing countries. A key dynamic that brings them to Botswana is the neoliberal agenda of the World Bank, which has been increasingly creeping into the public sector in many countries. For Botswana, this comes not as a surprise as the government is renowned for its strong conviction in the free market as a vehicle for development and prosperity. However, what is surprising is the idea being peddled by government bureaucrats that these changes are mainly initiated from within. It is argued that the involvement of networks of international organisations in Botswana's reforms dispels this myth. The paper demonstrates how earlier concerns raised by the World Bank, of low productivity in Botswana became materialised with the assistance of a number of consultants from international institutions, who provided varied support to the government of Botswana. For example such assistance came in form of financial, intellectual, and training of government officers. It is from the role played by these international institutions that the national structures and mechanisms have changed the public service. This has eventually led to neoliberal reforms in the form of Performance Management System being the accepted dogma for improving productivity in the Botswana public service.
\end{abstract}

Key words: public sector, global institutions, neoliberal, hidden hand 


\section{Introduction}

If Adam Smith's invisible hand of the market works then one way in which it operates today is through global institutions. These institutions are structures and mechanisms used by various powerful persons and groups within Botswana whose goal is to increase productivity and efficiency in the public sector to deliver value for money services to the taxpaying end-user. This goal is pursued through a programme which Hope, (1995) captured as "rapid change" and is, almost always, associated with privatisation. Yet these institutions are also structures and mechanisms produced and maintained by powerful persons and groups on a global scale, whose goal is to ensure nothing stands in the way of making, and sustaining profit and, thereby, accumulating capital. The current policy used to pursue this goal boils down to a policy of removing all fetters or restriction on markets. One such market is, of course, the labour market. Removing fetters here necessarily involves radical alteration in the organization of work in order to ensure that organised labour does not "buck the market", that is, operates according to market principles. In sum, these institutions are designed to promote a neoliberal policy agenda.

This global goal is pursued at the national level precisely through these programmes of reform the public corporations and privatisation. Without grasping the global picture, then, we are unable to fully understand the national picture and it easy to slip into taking these national goals at face value. That is, it is easy to slip into assuming that the goal is just one of pursuing productivity and efficiency gains per se instead of also, or perhaps primarily, one of pursuing profit and the accumulation of capital. Grasping the global picture, however, allows us to explain national policy as part of a global policy agenda of neoliberalism, and encourages us to see beyond the stated goal of increasing productivity and efficiency. In Botswana the neoliberal public sector policy reforms go under the umbrella of performance management system (Marobela, 2008).Compared to the other previous initiatives aimed at enhancing performance for example, Work Improvement Teams (WITS) the recent management reforms introduced by government will go down as the most expansive and radical in the history of Botswana public sector transformation (cf. Marobela, 2007, BIDPA-UNCEA, 2004) Never before has the government embarked on a restructuring of the civil service in such a form, scale and speed. And hence the title of our paper "the reshaping of Botswana public service"

\section{Botswana's Economy}

Botswana is widely considered a unique country in Africa because of its relative political stability and economic growth. At independence in 1966 from British imperialism, Botswana was an extremely poor country and highly dependent foreign aid (Colclough and McCarthy, 1980). Today the country has experienced the highest world sustained economic growth. Accordingly, Botswana's developmental trajectory has been cited as exceptional in Sub-Saharan Africa with an unmatched economic history (Leith 2000). However, this exceptionality is contested and indeed challenged by Good (1992) who posits in spite of its notable progress, Botswana's economy has created deep inequalities which poses a real danger to its long term stability. 
Such a contradictory developmental trajectory described by Jefferies and Kelly (1999) as "Poverty Amid Plenty," is typical feature of capitalist development, which manifest in "combined and uneven development" in the distribution of wealth. For example Botswana, has huge income inequality, extreme poverty and mass unemployment. All of these exists alongside it's a staggering wealth (BIDPA and World Bank, 2006).

Different reasons have been advanced for Botswana's celebrated economic performance, for example former president, Mogae (2005) cited political leadership as one factor. Undoubtedly, it is the diamond mining which is a critical factor to this growth and success. Botswana is almost entirely dependent on the mineral extraction industries, especially diamonds. Diamonds accounts for $33 \%$ of the GDP and over 50\% of Botswana's revenue (Debswana, 2003; Bank of Botswana, 2007). More significantly, 70\% of government export revenue is accrued from diamonds. This dominance has been a challenge to government because in spite of this splendid, performance the diamond industry only provides employment to about 6000 people, the state providing the bulk of employment. (Republic of Botswana, 2006) From above, three problems from the economic structure arise which define the relationship between the state and business. Excessive dependence on diamonds, however, renders the economy susceptible to any downturns in world demand. For example if the looming global recession results in a wide economic crunch, Botswana's diamond export sales-revenue is more likely to be affected. The dependence on this highly mechanised sector means also that the country maintains a rather narrow industrial and skills base, and discourages economic growth and diversity in other areas. Thus, Botswana is constantly in a rather precarious economic position of permanent crisis because of excessive dependence on primary products such as mining. This dependence, especially on diamonds, poses a serious danger to economic sustainability in the long term when diamonds are exhausted.

This scenario fuels the drive for alternative sources of economic growth and sustainability. And for free market Botswana the route is through private sector investment, as government has declared it "the engine of growth" (Republic of Botswana, 2003, Republic of Botswana, 2012). Hence the government of Botswana has been desperately trying to attract foreign investment (FDI) as illustrated by the formation of a foreign investment institution Botswana Export Development Agency (BEDIA), which it is assumed will help overcome these problems even though from the past four decades the private sector investment led growth has not materialised nor has the economy diversified as planned through private sector led initiatives. Moreover, such restructuring creates more problems, like unemployment (Chesnais 2004) from privatisation. This is a problem for Botswana because the level of unemployment is already high. So the unbundling of the public sector is one alternative which is viewed as a solution from two perspectives. Freeing the government from large expenditure associated with large employment and privatising state owned enterprises to create more jobs. Hence the ongoing attempts radically reform public service with World Bank inspired management initiatives — performance management system (PMS). 


\section{Methodology}

Data was collected over time from different sources. The primary source was documentation and interviews with government officials and workers organisations such as trade unions. Unlike positivist research which seeks large sampling to make a case for generalisation and prediction. Our approach was exploratory hence convenience sampling based on key respondents was used backed by descriptive data from achievable sources for example the internet.

The method used to understand these changes is what critical realists call the causal-explanatory method (Ekström, 1992; Fleetwood and Hesketh, 2006). The objective is to explain, and explanation is carried out via an analysis of the underlying factors. In this case, our interest was on generative or causal mechanisms responsible for shaping the working practices introduced in the public sector. These generative mechanisms are the (macro) pressure coming from global institutions and passing through regional and national level (meso), ending at local (micro) level. The macro, meso and micro context is necessary because our study of Botswana reforms shows a similar pattern with other reforms that have been introduced in other countries. They are globally shaped and driven by a range of institutions as mediators of public service reforms in keeping with the neoliberal agenda. Hence the character and form assumed by these global players is examined in relation to recent management reforms introduced in the Botswana public service. It is argued that these global institutions are not neutral but have an agenda, which is, to promote global capitalism. Their idea of public sector efficiency and delivery is one in which governance is predicated on the neoliberal project of privatisation (Harvey 2003).

Understanding this requires both theory and meta-theory and here we make use of critical realism. In addition to employing the causal-explanatory method, we also apply critical realism as a meta-theoretical perspective to understand and explain Botswana public service reforms and their association to the global forces shaping them, we employ Bhaskar's Transformational Model of Social Action (TMSA)), with an illumination by Archer's (1995) morphogenetic framework. Archer's work is particularly useful here because of her emphasis is not only on transformation but also the reproduction of structures via the notion of emergence. Central to critical realism is ontology, and central to the ontology adopted by critical realists is the view that the social world is stratified with emergent powers and mechanisms. Thus in this sense they are mechanisms of profitability and accumulation helping to pave the way to change the nature of public services and ultimately create conditions that open up new opportunities for profit making in the public sector by for example outsourcing.

\section{Literature Review}

In terms of Botswana's public sector reforms, transformation is seen as stratified because it is mediated at three different levels - macro, meso and micro. Using this three-layered analysis, a phenomenon is broken into separate but interrelated parts of a whole. One of the elements of this model is resolution, where a complex phenomenon under investigation is reduced into simple components. Through causal analysis, an attempt is made to define the 
causes (of transformation) by posing an alternative theory (Collier, 1994). Thus, for instance, this alternative view challenges the prevailing view that the real purpose of the new reforms being implemented in Botswana public service is just about productivity. Rather, the reason for introducing new reforms is to pursue the goals of profitability and accumulation of capital.

Regarding causal mechanisms this is linked to the context of transformation. In this respect I show that there are different mechanisms in operation and with respect to the Botswana reforms these causal mechanisms assume different roles. Global institutions for example are not per se involved in implementation but work behind the scenes (unobserved causal mechanisms as realists put it) by providing the underlying resources and ideas to justify the need for restructuring the public service in general. The concept of a performance management system is a case in point. But these global mechanisms do not operate by drawing ideas from thin air. They have emergent powers drawn from the sedimented interaction of past structures and certain powerful agents. It is argued that these structures and agents are the driving forces for the capitalist neoliberal ideology of New Public Management (NPM). This is an idea that emerged from an analysis of the material or objective conditions of a capitalist system characterised by over accumulation and economic crises.

Governing the actions of human agents are a range of social structures. Critical realists tend to use the term 'social structure' as a portmanteau term to refer to mechanisms, resources, rules, relations, powers and so on. The key point is not really what we call them, but that they are phenomena that are radically different things to human agents, and that constrains and enables agents to engage in actions and in this sense have causal properties. This is why they are sometimes referred to as causal or generative mechanisms. Henceforth I will refer to the structures and mechanisms, or where necessary, to the structures and mechanisms that constrains and enables human action.

Archer's morphogenesis and morphostasis approach (MM) is useful in explaining the interplay between structure and agency. Moreover, it provides sufficient grounding not only for identifying the stratified nature of these causal mechanisms but it also helps to account for their emergence through history. In this perspective ideas which are embedded in structures and agents are in part a reflection of the history and the present state of the capitalist mode of production.

By focusing both on structures and agents as separate yet part of the totality, critical realism avoids committing mistake of voluntarism which locates the cause of change on agency and reification which locates the cause in structure (Archer etal, 1998). Following Thursfield and Hamblet's (2004) application of morphogenetic approach in Human Resources Management (HRM), we identify the emergence of the agents shaping Botswana public service reform to the introduction of performance management system, a human resources management strategy brought in to improve performance in the public service. This is done by examining the broad goals of global institutions and how these goals relate to and shape the implementation of the new government reforms through notions such as governance. Let us proceed, by considering the background against which current changes in Botswana are set. After that, our attention will focus on the specific institution, namely, the World Bank. 


\section{The Capitalist Crisis and Global Institutions}

The crisis of capitalism pressures capitalists to expand, invest, generate profit and accumulate capital. And with this expansion global capitalism shapes the world economy. Central to the spread and reproduction of capital has been the mediating role of global institutions like the IMF, WTO, World Bank and United Nations not only promote neoliberal policies but impose them as the mantra for the world economic system (Saad-Filho, 2003). The current global economic crisis stem from the quest to accumulate on a world scale.

Today, under the new world order which some have called 'monopoly capitalism' the interests of international finance capital are of special importance. It has been argued persuasively that global expansion and competition serves interests of transnational corporations mainly from the rich countries (Goldman, 2005). Though they are forced to compete with each other, they are also forced to cooperate in a globalised economy to realise their interests. A case in point is the 2001 legal case by a grouping of 39 multinational pharmaceutical companies who tried to prevent the South African government from passing a patent law that will allow it to buy cheaper HIV/AIDS drugs (Boseley, 2002; Usdin, 2003).

It is such interests that lead to the formation of a number of global institutions, such as, the Western -dominated triad comprising of World Bank, the IMF and the WTO. The reform policies of these supranational institutions which are controlled by the US, hence the name 'Washington consensus', are a mechanism used to impose a uniform globalist policy (Petras and Veltmeyer, 2001).

Their push for a neoliberal agenda based on free trade as a panacea to the problems that bedevil capitalism has, for instance, resulted in an opening of the markets of poor countries to big corporations from the rich countries. While the rich countries preach free trade they are not willing to abolish heavy subsidies on agriculture for example, France and the US. And yet, these developed countries want developing countries to liberalise their economies to attract Foreign Direct Investment (FDI). But ironically the poor countries gain little from FDI.

These institutions are the pillar behind what has been referred to as 'trickle down economics,' the idea that wealth can be created for society through the market. The policies that they prescribe to the developing world could be termed as colonial economics because they promote economic dependence of the poor countries on the rich. For this reason Cheru has compared their role to that of missionaries, "The old Christian missionaries have been replaced by an army of Western neo classical economists who peddle their 'free market' ideology, which, it is hoped will take Africans to the 'Garden of Eden' (Cheru, quoted in Mihevc 1995).

In addition, Pilger (2002) has pointed out that the notion that the market is best at allocating resources has been a mockery for people in the developing world because with more liberalisation their living standards have worsened not improved.

Thus the consequences of the neoliberal reforms, have been mostly felt by the poor in the Third World, many of who live miserable lives because their governments have been forced to cut subsidies in health, food and other essential services, resulting in millions dying. Kim (2003) argues that the neoliberal solution imposed on Africa by global institutions as a model 
for development and economic progress is, in fact, out of step with the reality because it has instead through austerity requirements of structural adjustment programmes (SAPs) impoverished ordinary people, creating unemployment and enriching multinationals via liberalization of the market and privatisation of the public sector (cf. Kim, 2003)

The collapse of the 2003, WTO talks in Cancun, Mexico was the last straw. In the past, poor countries have swallowed the bitter medicine silently, whilst the unpopular structural adjustment policies, now renamed as 'poverty reduction and growth policies' have contributed to the disasters and miseries of many people in the developing world. Now the poor countries seem to have come to terms with reality.

It is the misplaced policies pursued by these powerful institutions that have impoverished rather than empowered developing nations. To these countries free market ideology meant, for example, the abolishment of state subsidies, which resulted in a massive increase in the price of basic foodstuffs. Ironically, the West does not see any need to remove heavy subsidies on their own agricultural products that effectively make products from the developing world less competitive. Together with the WTO, these two institutions played a crucial function in the mis-governance of developing countries. The civil service reform (CSR) framework that has been adopted by many governments in sub-Saharan Africa echoes the dominant ideas that are propagated by this neoliberal axis. Developing countries who badly need funds have been forced into reforming their public sectors as condition for getting loans or grants (Stiglitz, 2002).

This seems to supports what Corkery and Land (1997) have found when they suggest that because multilateral agencies such as the World Bank and the United Nations Development Programme have control over resources needed by developing countries, they are able to exercise influence over public policy. Moreover, they contend that these institutions are increasingly involved in public service reforms.(http://www.one world.org/ecdpm/pmb/b7f_gb.htm).

This is the context from which the public sector changes are implemented. They revolve around the problem of governance. It is under this theme that the idea of liberalisation comes in, the objective of which is to change the role of government to facilitate market expansion into the private sector. Thus, the image of government as wasteful and inappropriate at managing public enterprises is normally vigorously trumpeted. Invariably, apologists of the market have one solution to public service governance: introduce the market. They suggest for example that government should 'hive off' some of its functions to the private sector because the market has become sine qua non for efficiency and better delivery. This is why private sector management practices such as PPP, out-sourcing and contracting underpin the public service reforms in Botswana. Figure 1 is a schematic presentation of how the relationships between the different levels of institutions are linked to promote the neoliberal agenda in Botswana. 
Fig 1 : Global, International and National Connections

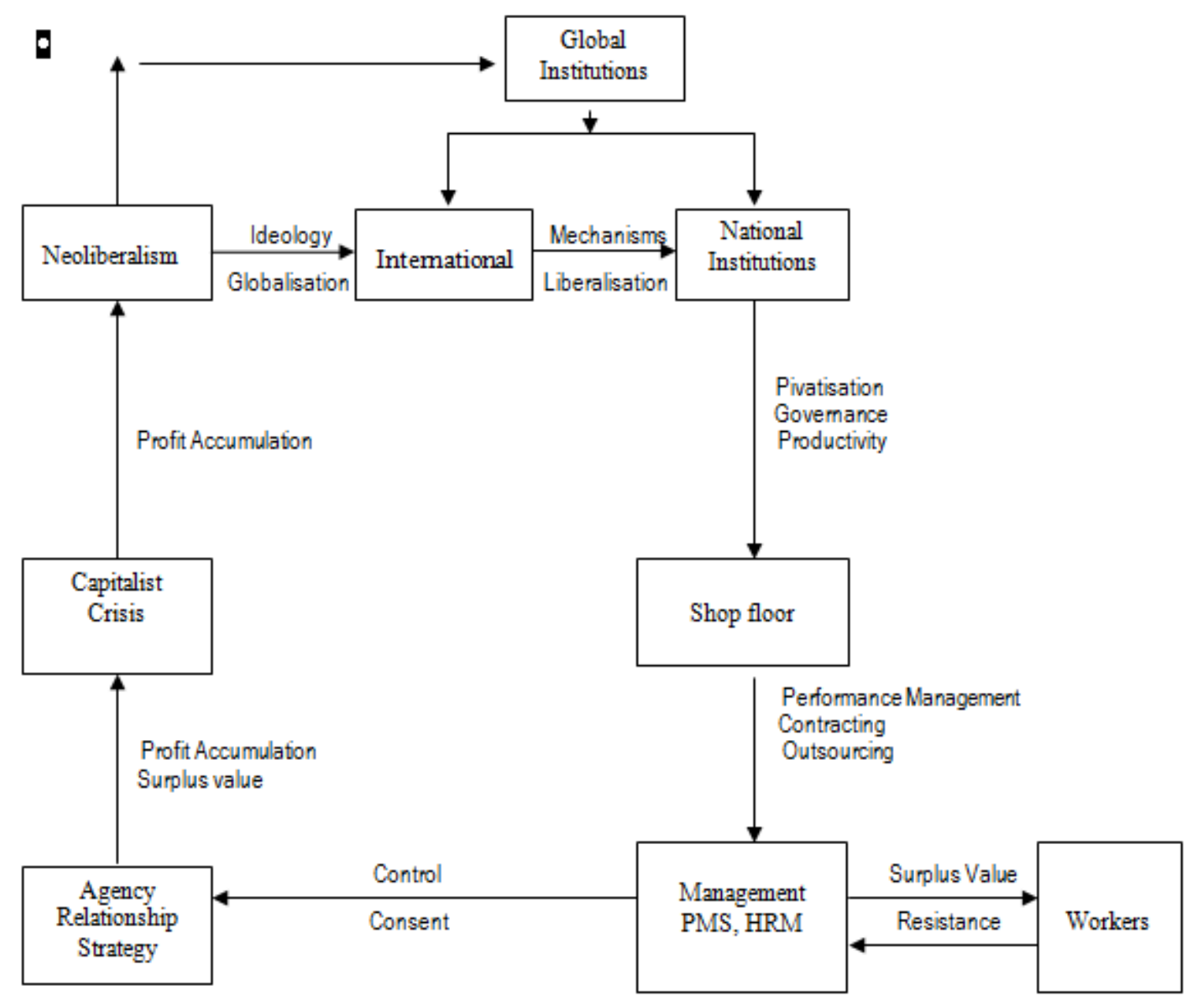

Source: Marobela, 2011

But there are also costs that follow from pursuing this agenda. Deep reorganisation of work also means profound consequences for the labour process, as we shall see later from the case of Botswana Police Service. The Botswana case shows that two global institutions are shaping the management of the civil service, the World Bank and the United Nations Development Programme (UNDP). There is ample evidence to suggest that the 1997 public sector reforms in Botswana were part of a long process of change with the influence of these institutions.

\section{The World Bank and the Good Governance Mantra}

Investigation of the World Bank is often limited by failure to examine the historic mission of the Bank.

Mainstream economic research mostly focuses on its governance role without showing how this tie with the wider historical agenda of the Bank in relation to political discourse. For instance, notions such as good governance, corruption and foreign investment are normally examined outside the political ideology which drives the Bank projects. In this respect, a 
reductionist analysis based on positivist relationship is used to draw conclusion on cause and effect like using categories such as poverty reduction and foreign direct investment (cf. Mauro, 1995, Wei, 1997, Kaufmann, et al. 1999, Chong and Calderon, 1999).

On the other hand, a critical perspective that links policy with the politic is important to understand why the Bank's long promises of improving the lives of ordinary people in the developing world has in fact made things difficult if not worse. This is done by a critique of the history imperialism and colonial policy of development, for example structural adjustment programme. According to Goldman (2005) the development trajectory between the North-rich and South-poors, cannot be explained outside the historical context of capitalist accumulation. Specifically the power dynamics between the metropoli and the colony, Goldman agues that the colonial "development discourse" based on exploitative relationship continue to shape the relationship. Its initial objectives were to provide reconstruction and development as well as facilitating capital for productive investment (Caufield, 1998). This mandate offered it a wide scope of intervention, including offering loans support to governments in the developing world in areas such as health, education, trade and infrastructural development. However, from the 60s the Bank broadened this mandate with poverty becoming its core mission. Hence according to (Caufield, 1998: 330), 'every president since MacNamara has said that poverty reduction is the Bank's chief objective' The World Bank confirms this when they suggest that poverty reduction is its overarching goal (World Bank 2003:4) World Bank Group is an elaborate structure has thousands of highly trained and paid consultants who are working in different disciplines across the world. It is these experts who work closely with government's ministries and non governmental organisations in different countries. In addition, the Bank's consultants have established networks with international and local think-tanks and through such mechanisms the World Bank is able to influence public policy to project World Bank power, (Goldman, 2005). According to the World Bank publication, 'A guide to the World Bank, 2003', over a hundred countries in the developing world are members of these grouping. According to the Bank its strategy in Africa advances Millennium Development Goals and also promotes New Partnership for Africa's Development (NEPAD) (World Bank, 2003:83). To many millions of Africans who leave below $\$ 2.00$ a day both of these principles remains but a long pious pipe dream (World Bank, 2003:83).

Over years the World Bank has engineered profound changes in the world economy through their structural adjustment programmes (SAPs), now renamed poverty alleviation because of pressure from the anti-globalisation groups on the efficacy of their policies (Mihevc 1995) The spread of these ideas has been in part a response to capitalist crisis. World Bank intervention is meant to ameliorate this crisis by creating, on a global scale, conditions that further accumulation (Cammack, 2003). A case in point is lending. The World Bank loans to Third World countries are conditional some of the lending conditions for infrastructure projects require that multinationals from the lending countries carry out these projects, some of which have been have been found to be white elephants such as big dams. In effect, such loans accumulated into huge debts making banks and financial institutions from the West benefit through accumulated interests. But this has to be paid by the ordinary taxpayer not the national bourgeois (Marfleet, 1998). This debt crisis shows how global accumulation is 
mediated via the policies of the World Bank and other international institutions such as the IMF. Further, it demonstrates the contradictory nature of capitalist development because it is now the poor who are financing the rich countries instead of being the recipients. Hence, to get more aid and donor assistance many developing countries, particularly in Africa, had to conform to this programme hoping that such conformity will help them grow and develop (Krugmann, 1995:139)

Ironically, instead of helping developing countries get out of the economic poverty, SAPs seem to have made the situation worse. According to Mihevc (1995) structural adjustment does not merely denote a set of economic policies to assist countries in addressing structural problems related to trade, growth and balance of payments. Structural adjustment also, and most profoundly, embodies a social, cultural and religious vision, not only for Africa, but also for the world. This vision is about global capitalism. The World Bank, through its governance mantra has sort to reorganise the world economy along this order of 'neoliberal, market led globalisation' (Jessop, 2002). While the World Bank admits that 'globalization has created both progress and problems' (World Bank 2003) however, more problems than good has been caused by their neoliberal globalisation and therefore they must own up to this mess. As (Sau, 1978:112) has argued, 'the current abuses of the day, the poverty, degradation, exploitation and misery are the direct consequences of the existing socio-economic formation'.

Third World poverty has little to do with population control as former World Bank President, Robert MacNamara worse alleged (Bauer 1981). This is true because while contemporary globalisation has generated immense resources poverty remains rampant not because there are too many people rather the problem persists because of neoclassical competitive model preached by the World Bank. But the Bank has still to come to terms with the real cause of what the call 'extreme poverty' in the developing world. Part of this problem comes from their globalisation reflected in the reforms they are promoting in public sector:

A fundamental role of the Bank Group is to help the governments of client countries function better. Although this role is simply to define, it is both complex and difficult to accomplish. The Bank Group has a number of initiatives dealing with governance issues, including public sector group activities, public services research, and World Bank Institute (WBI) governance and knowledge sharing programmes. The Public Sector Group is the lead unit in this area and is responsible for the World Bank's governance and public sector strategy. The unit focuses on building efficient and accountable public institutions, rather than simply providing policy advice. Its work reflects the understanding that good policies are not enough - that the Bank Group cannot afford to look the other way when a country has deeply dysfunctional public institutions that limit accountability, set preserve rules for the game, and cannot sustain development (World Bank 2003: 126).

Their role goes much deeper than simply defining what good practice is. Through publications, workshops and seminars targeting senior government officials, as well as working with international and national think tanks the Bank is in a position to use such mechanisms of to prescribe the discourse of governance. Their view of efficient delivery for example is invariably linked to privatisation and downsizing the public sector. Structural adjustment has contributed towards this trajectory as mechanism used by the World Bank to 
influence economic policy. Hence governments especially in the developing countries were pressured into privatisation under the guise of what the World Bank call 'good governance'. The result of this is the sale of state owned enterprises. Pilger (2002) suggests through this policy, the Bank managed to destroy public services, which provide the poor with essential facilities such as power, water health and education at subsidised rates. The impact of the World Bank policies and strategies in causing misery for the ordinary people is well documented (George, 1976; Mihevc, 1995; Caufield, 1998: Marfleet, 1998). It is not the intention of this paper to go deeper into this. Suffice to give a few examples to illustrate that contrary to their goal of fighting poverty, some of the Bank's programmes have in fact caused a decline in living standards in the developing countries. For example in Malawi the removal of government subsidies on fertilizers to small farmers as recommended by the World Bank caused a lot of hardships for the poor (Chipeta, 1993:115). In Africa, their core mission has been to transform the civil service through management reforms aimed at downsizing government workers (Adamolekun and Pinto, 1995:203).

In Southern Africa the World Bank has been active in shaping both economic and social policy. Some of its impoverishing policies include the privatisation of the Zambian strategic copper mines and state-owned enterprises to the introduction of user fees in hospitals and schools. Thus a former Zambian Miner who was retrenched lamented 'privatisation has brought more misery than benefits' (Mmegi Business Week, 20 January 2004).

Now Botswana is following this trend with its new reforms in the public sector. The World Bank is currently working on the privatisation of Botswana's only national airline. The Bank is also an advisor to government on the proposed new university, which is funded through public private partnership. And some of the state owned enterprises are retrenching workers as part of the privatisation process. The consequences are cuts in public expenditure and the government recent cost sharing measures that introduced school fees charges. All these new changes bear the hallmark of the Bank economic strategy.

As a global financial power, the World Bank has enormous influence (Caufield, 1998). It was therefore not by accident that a Motswana youth leader recently appealed to its vice president, Ian Goldin, to put pressure on government, 'I know that the World Bank is powerful and influential body and we would like you to exert influence on our government so that they can listen to our plight' (David Maswabi, speaking at the Civicus World Assembly in Gaborone, Botswana, Mmegi Wednesday 24, March 2004).

Sometimes the Bank have used this power to punish countries that refuse to adhere to its prescribed policies, as Adepoju (1993: 4) points out that 'Zambians found the conditionalities too harsh and the government broke with the IMF agreement. Subsequently the IMF and the World Bank stopped funds to Zambia'. This joint punishment is not surprising because membership of the World Bank requires that countries also join the IMF. Notably, it is their involvement in post apartheid South Africa that the World Bank played a highly influential role in the African National Congress (ANC) new macroeconomic strategy called Growth Employment and Redistribution or in short GEAR (Bond 2000). Despite the denial of the Southern African government about World Bank influence, the Campaign Against Neoliberalism Group has argued that GEAR is a neoliberal economic policy that has take 
from the World Bank model. And in fact the Bank economists helped to draft this policy (Southern Labour Bulletin, 1996:24). The effect of this has been privatisation of public services in South Africa. And as is to be expected it is the poor who have to pay a high price in this step to neoliberalism by paying more on basic necessities like water and electricity. Those who cannot afford to pay are shut off. It was this that forced ordinary people in South Africa who were disconnected electricity by the state to reconnect themselves power illegally. This is how the World Bank policies affect the poor in the developing world, the majority of whom are poor.

In Niger, for example, the French water multinational Vivendi upset residents and 'caused much dismay and shock' when it increased the price of water. This case is reminiscent of the Bolivia water experience, where another multinational raised the price of water following privatisation, a move that prompted ordinary people to revolt. Similarly, in South Africa, Ghana and India, people have campaigned against the privatisation of water. These cases illustrate the extent to which the World Bank serves interests of multinational corporations, not the poor, as it claims.

\section{The World Bank and Public Sector Governance}

Kulshreshtha, (2008) ne area where the Bank promotes this agenda is with respect to the public sector. Invariably, the World Bank sees the problems of Africa from a political crisis perspective stemming from the bad governance. As one of the their advisors put it, 'the root causes of the inefficiencies and poor performance of the civil service in Africa are more institutional (governance) and structural (incentives framework) than technical'. It is this agenda of modernization and rationalization that is behind changing the public services (World Bank, World Development Report 2000-2001:100).

Today the World Bank continues to shape governance in developing countries. Most of the civil service reforms (CSR) framework that has been adopted by many governments to reform their public sectors mirrors the ideas that are propagated by the Bank as necessary for efficient administration. This is clear in some of the seminars they have hosted in developing countries. For instance, they were active in two such seminars, Civil Service Reforms (CSR) in Anglophone and Francophone Africa. In addition, they have written numerous papers (Rondinelli, 1984; Shields, 1986; Paul, 1991; Dia, 1993; Adamolekun et al, 1996) with a view to clarifying a framework that could be adopted by countries to reform their public sector. Indeed, they have done extensive work associated with reforming the public administration, notably it is in Africa that their mark has been most felt as they have succeeded in influencing many countries to accept their agenda by agreeing to restructure their civil service along specific lines. For example, in one of their technical paper series on Africa, called 'A Governance Approach to Civil Service Reform in Sub-Saharan Africa, the Bank argues for privatisation, contracting out the use of performance targets to address the perceived problems of public sector management in Africa (Dia, 1993:35-36).

\section{World Bank in Botswana}

The World Bank has been involved in Botswana for some time; the country joined the World Bank in 1968, just two years after independence from British Empire. And became a member 
of one of its prime subsidiary, the International Finance Corporation (IFC) in 1979 (www.worldbank.org/afr/bw2.htm). Botswana is now a full member of the 'World Bank Group' (World Bank 2003:162).

From the early 1980's the Bank were providing 'technical support' in areas such as health, finance and education. In addition, their intervention also extended to public administration. Available literature shows that one of their rudimentary works in the Botswana's civil service probably dates back to the early 1980's. For example, in 1984, the World Bank staff conducted a study called "Public sector Management in Botswana-lessons from pragmatism". The findings of this research praised Botswana for sound economic management and effective public sector (See, Raphaeli, N. et al. (1984). Shortly thereafter, the Bank carried out a regional study in 1986, called 'Public Administration and Management' issues for Botswana, Lesotho and Swaziland (BLS). It seems for a period of two years things have dramatically changed in the management of Botswana public sector. With respect to Botswana, the Bank outlined the background and objectives as follows 'This study arose out of the concern by the World Bank, Botswana Government, and other agencies that management is a constraint on development and that there is need to strengthen the institutional capacity of Botswana to manage its economy assistance (World Bank, April 21.1986:3-4).

It was in this extremely influential report that the Bank emphasised the need for government to adopt the 1985 national productivity seminar recommendations. The major outcome of the seminar was productivity and civil service reform. Further, the Bank extolled government to establish a committee within the directorate of personnel, now called, Directorate of Public Service Management (DPSM), as a mechanism that would ensure that the outcome of the productivity seminar are put into practice. In a chapter termed "Agenda for Change" they called for a momentum productivity and set the implementation framework through placement of external consultants at the then Directorate of Personnel and Department of Labour (World Bank, 1986:51)

It is almost impossible to overstate the importance of the national productivity seminar and DPSM. These institutions were highly influential in establishing the principles upon which later reforms were based. As shall be shown later it was the same recommendations, which emerged from the productivity seminar that were used again to justify the new PMS driven reforms.

Another major work that also goes to illustrates profound involvement of the World Bank in Botswana is their study 'Botswana, Opportunities Industrial Development in Botswana: An Economy in Transition', from 28 April 1993. It could be argued that through this work the Bank took major influence on the future of Botswana's development particularly shaping its economic policy (World Bank, 1993:118).

One of the themes, which, the report emphasised, is the issue of labour productivity. The Bank was concerned about what it called 'low productivity and declining levels of labour productivity'. According to them part of the problem lied with salary increases in the public sector which, they suggested, were putting upward pressure on the private sector salaries 
hence rendering them less competitive: (World Bank, 1993:61).

Their solution to increased productivity was a flexible approach to work. Thus instead of paying a minimum wage, the Bank, for example, recommended that government should consider the use of piece rate system. The implication of this is that those deemed to be performing poorly can be paid less. But in Botswana, the minimum wage is the barest income, and therefore cannot sustain a worker. Compared to the high costs of living in Botswana, a minimum wage is in a way a poverty wage. This is why the Unions rejected it and demanded a living wage. How ironic that the World now talks about poverty alleviation, when they have in the first place encouraged it.

The Bank made it explicitly clear that Botswana needs to adopt a flexible wage regime to alleviate low productivity and enhance competitiveness. It therefore comes as no surprise that it was the Bank, which funded the initial study that led to the reengineering of the Botswana public service. The outcome of this was the introduction of performance management systems. To implement this they had to relate with a number of other international institutions that are mainly manned by various overseas management consultants. The US-based Academy for Educational Development (AED) carried out the performance management study and The Performance Centre (TPC) provided training. From UK, the Adam Smith Institute and the Commonwealth Secretariat are involved in the privatisation of state enterprises.

Locally a number of institutions have been working closely with international agencies some of which includes the above named. The government think tank Botswana Institute for Development Policy Analyses (BIDPA) and the Botswana National Productivity Centre (BNPC) were central in tailoring neoliberal ideas to suit the local situation. At government level, the management services unit of the Directorate of Public Service Management (DPSM), a government consultancy arm, have been instrumental in providing the legitimacy for reforms. Their transformative agenda involve the two-step process of 'unfreezing' old public sector values and then replacing them with new ones. This occurred in the public sector for example by unfreezing old values of the public sector for example job security and then introducing new visions and mission statements in ministries and departments. Essentially the new values entail the adoption of private sector management ideals, values, beliefs and techniques. These institutions were not only instrumental in establishing new ideas, through the Performance Management System, more and more government work began to be outsourced and contracted out to private companies.

The privatisation policy is now dismantling public corporations. Further influence of the World Bank is seen from the fact that its subsidiary, International Finance Corporation (IFC) has been involved in the botched privatisation of the national airline, Air Botswana. More recently, IFC is involved with the privatisation of Botswana Telecommunication Corporation (The Tswana Times February 14, 2008). In addition, the IFC is also advising government on public private partnership on the new university (Botswana University of Science and Technology) another Word Bank division, the Foreign Investment Advisory Services (FIAS), carried out a study on: 'Administrative and Regulatory Barriers to Investment in Botswana' in which it called on government to do more to attract foreign investment. They are quoted as 
saying 'the country is still faced with a raft of impediments to attract FDI' (Mmegi, 12.03.2004). As noted the World Bank has strong working relationship with the government think tank, BIDPA. In 2006, they were engaged in the study on "prospects for export diversification in Botswana". Further to that the former Director of Botswana Institute for Development Policy Analysis (BIDPA), Happy Fidzani, disclosed that his organisation is to undertake a World Bank funded study called ' Economic Diversification in Botswana: Obstacles and Prospects' (Mmegi, 2 February 2004). The study has since been completed.

More recently, the World Bank has been involved in rationalization and privatisation of water in Botswana. As a consequence of its study the water affairs department which provided water cheaply to people in rural areas was disbanded and replaced with the profit motivated Water Utilities Corporation (C.f. www.bw.gov.bw/en/Ministries--Authorities/Ministries/Ministry-of-Minerals-Energy-and-Wat er-Resources-MMWER/FAQ/)

All this demonstrates that the World Bank has played, and continues to play a significant role in shaping Botswana's political economy. Although on the surface it would appear that the Bank is not involved, a closer examination of its activities and publications shows otherwise. This is given credence also by talking to people, who confirmed the involvement of the Bank in the ongoing transformation of the civil service in Botswana.

According to the Coordinator of Public Service Reforms (PSR) at the Directorate of Public Service Management (DPSM), the reforms that are being implemented in the civil service came as a result of a study that was sponsored by the World Bank in 1996. This was corroborated through an interview I conducted with the head of Public Service Programme (PSP) from the Botswana National Productivity Centre (BNPC). She revealed that she was part of the consulting team led by an American professor. Furthermore, these views are supported by the government report on implementation of public service reforms. This report makes it clear that 'the World Bank provided funds to support that consultancy' (Republic of Botswana, DPSM, 1998:5).

More evidence on the World Bank connection to the ongoing reforms in Botswana is given by the BNPC, in their 1997 pilot report on the feasibility of PMS, when they emphatically it note, 'The World Bank consultancy report of 1996 outlined a holistic approach to performance improvement in the public service... The implementation was to be guided by the World Bank report (BNPC, 1997:3). The last sentence is extremely important because even though another agency was contracted to do the study, in the end the report belonged to the World Bank. According to the former director of DPSM, 'the terms of reference of the study were among others things to assess the impact of various reforms that have been implemented by the government and to propose a performance management system, measurable standards for the assessment of achievements of agreed targets and an effective appraisal system' (Modise, 2000:4). The link between the World Bank and introduction of performance management in Botswana is also corroborated by a recent IDM consultancy report (2006) which also ascribed "the origin of PMS in Botswana to A World Bank consultancy report". 
Over the past two decades, the government of Botswana has instituted a number of performance improvement programmes aimed at facilitating productivity in the civil service performance. The background to these reforms which dates as far back to 1983 is given by the World Bank in its publication (World Bank, 1986:12). As shown earlier, the new reforms add to previous government restructuring. According PMS philosophy, a document, which explains the new reforms, since independence a number of reforms have been initiated in the public sector. Some of these include for instance: training and localisation, job evaluation exercise, organisational and methods review and parallel progression among others. Evidence from AED consultants, for example, suggests that concept of job evaluation in Botswana 'dates back to 1972.' Similarly, Kirangu and Mukandala (2003) have pointed out that Botswana stands out amongst other African countries for having implemented considerable reforms. To this extent Botswana is regarded as a model of public sector management. Perhaps it is for this reason that the country has been selected to host a regional Centre for Public Sector Management, the Centre for Specialisation in Public Administration and Management (CESPAM). The World Bank Institute is identified as one of the partners together with the Commonwealth Secretariat in this project.

(see also http://www.ub.bw/departments/social/cespam/HOME.htm)

It is significant to note that Botswana is frequently cited as one of the countries with a high quality public sector management in Africa (Raphaeli et al 1984; Wescot 1994; Clover 2003). Even the World Bank has long acknowledged this when they praised Botswana for civil service as characterised by careful attention to detail, planning, and dedication (World Bank, 1986:11).

However, there seems to be something of a contradiction in the way civil servants perform. On the other hand, it is being showered with praises for developing systems of good governance, on the other hand, however, Botswana' civil service is lambasted as highly inefficient and the PMS and privatisation suggested as the remedy ( Republic of Botswana, DPSM, 2000:33)

As the Bretton Woods institutions harp on the need to streamline the public service because it is a hindrance to private sector growth, economic pundits remember the tragedy of structural adjustment in the 1980s and '90s. The World Bank's Vice President for the Africa Region said Botswana's civil service has become "maxed out" in terms of employment opportunities and its size and dominance are squeezing out the private sector from spearheading a new era of growth for Botswana. Obiageli Ezekwesili's comments reinforced the World Bank and IMF's criticism of Botswana's 159,000-strong public service, which represents 44 percent of total formal sector employment. "Deeper reforms to assist Botswana embrace private capital are going to be key. These would lead to capital accumulation, which deepens the market for investment, and citizens could take the opportunities that private enterprise offers. Reforms should aim at reducing government's high spending as a percentage of GDP. This would then give space to the private sector to be a provider and driver of growth."

The World Bank executive said while the considerations involving reductions in the civil service were complex, reform was inevitable. 
"One of the drivers is that whereas the public sector has been effective and efficient as seen over the years, it has come to the limits of what it can offer in terms of long-term growth and capacity to absorb more people in active economic engagement", she said.

According to the Bretton Woods institutions, Botswana's public service wage bill is larger than Lebanon, Malaysia, Mauritius, Chile, Gabon and Costa Rica's. However, locally, some observers have cautioned government to take the IMF and World Bank advice with a pinch of salt. Commentators at the recent Budget Pitso said the advice of the Bretton Woods institutions should be approached with caution. Said prominent economic commentator, Howard Sigwele: "A word of caution about the IMF and the World Bank: The IMF played a big role in structural adjustments in Africa in the 1980s and '90s, and it was a big mess.

"Even if they say we are over-staffed, take that with a pinch of salt because their track record in Africa is not something to be proud of. Whatever they say, let's not look at it as if it's the Bible. That would be a terrible mistake". (Mmegi. Friday 12 /10/2010. Mbongeni Mguni)

The inefficiency of the public sector is linked to the need to change. Privatisation in particular is seen as important help the country meet the challenges presented by global competition. This came clear from the Minister of Finance and Development and Planning, Mr Baledzi Gaolathe, in his budget speech to the national assembly. The minister noted that, to achieve this, the public sector will be reorganised in way that all ministries will be required to develop strategic plans containing visions and values with the objective of improving service delivery. To this extent the Performance Management System is regarded as an important enabling tool for high productivity by offering what government calls 'world-class service'. Further, he disclosed that staff will now be subjected to performance based pay to boost moral.

Botswana reforms are said to be unique in the sense that unlike other countries that have had to implement structural adjustment reforms under pressure, Botswana, is cited as one of the few developing countries without a debt problem (Botswana Government, 2000) and therefore not under any pressure from international capital to reform. Government officials are keen to stress that Botswana reforms are done to bring efficiency in the public sector. Indeed, former World Bank economist, Stiglitz (2002:36), has argued that unlike other developing countries who have been forced to implement structural adjustment reforms Botswana has introduced reforms without the pressure from the IMF.

This view is gradually becoming accepted as reflecting the uniqueness and prudence of Botswana's economic management. Now the ongoing civil service reforms in the public service are presented as a unique case of governance. Government bureaucrats describe the new reforms, for instance, as 'home grown reforms' in response to our problems. This is the message used to rebut sceptics who are inclined to challenge this position. But Botswana's emphasis on home ownership is not as such unique arguably it reflects the worry of global institutions and their shift in approach to avoid be accused of 'intervention and meddling in domestic affairs of sovereign states' (Abrahamsen, 2004:184) 


\section{Conclusion}

As already argued Botswana reforms bore the hallmarks being introduced under the spur of a capitalist crisis. As a dependent mineral economy with virtually no alternative employment base, the government of Botswana has been desperately trying to attract foreign investment, which is believed will to diversify the economy into other sectors and therefore create more job opportunities. It is from this looming economic crisis that the need for good governance becomes imperative for Botswana. Hence Botswana has little choice but to follow the dictates of capital. One of the consultants from the BNPC put it well when he suggested 'privatisation in Botswana: No Choice?' (Mangori, 2001). There are a couple of points worth making here. Whilst Botswana was able to resist pressure from Global institutions like IMF, it could not afford to turn its back on private capital. The indigenous capitalist class in Botswana were more than willing to embrace a shift in values that they knew would pay well with private capital. The World Bank has through different mechanism and structures penetrated not only the public service but the public sector as well.

Though unpopular and resisted in government (cf. Washington and Hacker, 2005). PMS has expanded and is now the management mantra in public institutions like university of Botswana, Botswana Post, Botswana Telecoms, Botswana Housing Corporation, and even private entities like Barclays Bank Botswana, where recently the Bank and its staff have been fighting, workers accusing management for using PMS to get rid of them. Could this be the case with government, recently government made it clear that they will cut budget by 5 per cent every year and announced the beginning of downsizing of its workforce. Curiously this announcing comes after recent persistent requests from both the World Bank and IFM to cut the wage bill and make Botswana public service "leaner and efficient" as recommended by IMF( IMF Press Release No. 11./206, May 31, 2011). The third world countries are concerned about the approaches adopted by the World Bank and the IMF in formulating their policies and the way they are governed. Because the power their wield in defining what is globally good for other poor nations ultimately has negative social and economic impacts on the live hoods of the people of third world countries who unwillingly pay a heavy price for the public goods following bad decisions the impose, what Friedrichs and Friedrichs, (2002 have called"crimes of the World Bank." In our view public services are not just about pushing performance standards and reducing costs to please bureaucrats, local politicians and the political agenda of global institutions. They exist for for public good and should remain as social safety nets for promoting welfare and equity, especially in the global South where despite the immense wealth created from globalisation, millions still survive on less than a Dollar a day, hence increasingly vulnerable if public services serve the market imperative than their real needs.

\section{References}

Academy for Educational Development (AED) (1996) Strengthening Human Resources

Management Capacity to Improve Productivity. Final Report November 28.

Academy for Educational Development Performance Management System: A Plan for Government-Wide Implementation. Final Report November 28. 
Archer, M, (1995) Realist Social Theory: The Morphogenetic Approach, Cambridge: Cambridge University Press: London.

Archer, M, and Bhaskar (1998) Critical realism: essential readings, London: Routledge.

Bank of Botswana (2006) Annual Report, Gaborone: Bank of Botswana

Bank of Botswana (2007) Annual Report, Gaborone: Bank of Botswana

BIDPA and UNECA, (2004) Botswana Institute for Development Policy Analysis and UN Commission for Africa (UNECA) The State of Governance in Botswana. Gaborone: Printing and Publishing Company Botswana.

BIDPA and World Bank (2006), Prospects for Diversification in Botswana, Gaborone, Impression House.

Boseley, S. Rights to Life. Guardian in Association with act! Onaid. 08.09.03

Caufield, C. (1998) Masters of Illusion: The World Bank and the Poverty of Nations Houndmills: Macmillan.

Chong, A. and Calderon, C. (1999) "On the causality and feedback between institutional measures and economic growth", The World Bank, Washington, DC.

Colclough, C. and McCarthy, S. (1980) The Political Economy of Botswana: a study of growth and distribution. Oxford University Press: New York.

Collier, A. (1994) Critical Realism: An Introduction to Roy Bhaskar's Philosophy. London:Verso

Ekström, M. (1992), "Causal Explanation of Social Action: The Contribution of Max Weber and of Critical Realism to a Generative View of Causal Explanation in Social Science" Acta Sociologica April 1992 35: 107-122,

Fleetwood' S and Hesketh, A. (2006) "HRM-performance research: under-theorized and lacking explanatory power", The International Journal of Human Resource Management. Vol 17, No.12, pp. 1977-1993

Friedrichs, O.D and Friedrichs, J. (2002) The World Bank and Crimes of Globalization: A Case Study, Social Justice Vol. 29, Nos. 1-2 (2002) 13-36

Good, K. (1992) “Interpreting Exceptionality”, Journal of Modern African Studies, Vol. 30 pp. 69-95

Goldman, M (2005) Tracing the roots/routes of World Bank power, International Journal of Sociology and Social Policy Vol. 25 Iss: 1/2, pp.10 - 29

Harvey, D. (2003) A Brief History of Neoliberalism, Oxford University Press: London.

Jefferies, K.R and Kelly, T.F. (1999) "Botswana: Poverty Amid Plenty", Oxford Development Studies, Vol. 27, No. 2,pp. 211-231

Hope, K.R. (1995) “Managing Development Policy in Botswana: Implementing

Reforms for Rapid Change," Public Administration and Development, Vol 15, 41-52. 


\section{Macrothink}

Journal of Public Administration and Governance ISSN 2161-7104 2012, Vol. 2, No. 2

Kaufmann, D., Kraay, A. and Zoido-Lobaton, P. (1999), “Governance matters”, The World Bank Policy Research, Working Paper No. 2196, The World Bank, Washington, DC.

Kaufmann, Kraay, and Mastruzzi (2006:).Governance Matters V: Aggregate and Individual Governance Indicators for 1996-2005.The World Bank Policy Research, The World Bank, Washington, DC.

Kim, K. S. (2003) Development Crisis in Sub-Sahel Africa: Globalization, Adjustment and Roles of International Institutions. Paper for CSI conference in Innsbruck, November, (www.uibk.ac.at/csi/paperconf2003/kim.pdf)

Leith, C. J. (2000), A paper presented at the Canadian Economics Association Thirty-fourth Annual Meetings University of British Columbia June.

Raphaeli, N, Roumani, J.and MacKeller, A. (1984) Public Sector Management in Botswana: lessons in Pragmatism, Washington, D. C, The World Bank

Wei, S. (1997). "How taxing is corruption on international investors?", Working Paper No.6030, National Bureau of economic Research, Cambridge. MA

Marobela, M.N. (2007), “The Political Economy of Botswana's Public Sector Management Reforms: imperialism; diamond dependence and vulnerability". Globalization Journal, globalization.icaap.org/content/v7.1/Marobela.html

Marobela, M.N. (2008), "New Public Management and the Corporatisation of the Public Sector in Peripheral Capitalist Countries," International Journal of Social Economics, Vol 25. No. 6, pp. 423-434.

Mauro, P. (1995), “Corruption and growth”, Quarterly Journal of Economics, Vol. 110 No. 3, pp. 681-712.

Mihevc, J. (1995) The Market Tells Them So. The World Bank and Economic Fundamentalsim in Africa. London: Zed Books

Mogae, F. (2005) Botswana's Development Experience, Lecture at the Institute of Development Studies, Sussex University. 21 February 2005

Petras, J and Veltmeyer, H. (2001) Globalization Unmasked: Imperialism in the $21^{\text {st }}$ Century. Halifax. Fernwood Publishing.

Pilger, J (2002) The New Rulers of the World. London: Verso

Kulshreshtha, P. (2008). Public Sector Governance Reform. The World Bank's framework. International Journal of Public Sector Management Vol. 21 No. 5, pp. 556-567

Republic of Botswana, (2003). National Development Plan 9, Ministry of Finance and Development Planning, Gaborone, Government Printer.

Republic of Botswana, (2006). Annual Economic Report, Ministry of Finance and Development Planning, Gaborone, Government Printer.

Republic of Botswana, (2012). Matambo, O.K. Budget Speech, Ministry of Finance and Development Planning, Government Printing and Publishing Services, Gaborone. 
Saad-Filho (2003) (ed.) Anti-Capitalism: A Marxist Introduction. London: Pluto Press

Stiglitz, J. (2002) Globalisation And Its Discontents. London: Penguin Books.

Thursfield, D. and Hamblett, J. (2004), "Human resource management and realism: a morphogenetic approach", in Fleetwood, S and Ackroyd, S (Eds.) Critical realist Applications in Organisation and Management Studies, London: Routledge

United Nations Development Programme, (2007), Human Development Report, Oxford: Oxford University Press, Oxford.

Washington, M. And Hacker, M. (2005) Why Change Fails: Knowledge Counts, Leadership \& Organisation Development Journal, Vol. 26 No. 5, pp. 400-411

World Bank Report (April 21, 1986) Botswana, Lesotho and Swaziland (BLS) Study of Public Administration and Management: Issues and Training Needs. Botswana. Opportunities for Industrial Development in Botswana: An Economy in Transition. (April 28, 1993)

Accountability in Public Services: Exit, Voice, and Capture Public Sector Management and Private Sector Development. (1991)

Civil Service Reform in Anglophone Africa. Proceedings of a Workshop held in Somerset, South Africa. (24-28 April, 1995)

Civil Service Reform in Francophone Africa. Proceedings of a Workshop, Abidjan, Cote d'Ivoire. (January 23-26, 1996)

Assessing Aid, Washington: cited in H. Nordas and A. Gergis (1998)

World Development Report, Washington, DC.(2007)

Botswana Guradian, December, 10, 2010; Cost of water to go up.... As profit driven WUC takes over; Justice Kavehematui

Mmegi, Friday 11 march 2011. New World Bank plan of support for Africa

Mmegi. Friday 12 November 2010; WB insists on trimming the public service

The Voicebotswana. Friday October 08,2010.

Sunday Standard, September 26-2 October 2010.IMF blasts Botswana's welfare state 